\title{
Keeping an open mind about meningitis: a case report of carcinomatous meningitis
}

\author{
Andrew Walkty, MD*+; Burton Abbott, MD; Neil Swirsky, MD; Janice Safneck, MD ${ }^{\dagger \S}$; \\ John M. Embil, MD*
}

\section{ABSTRACT}

Carcinomatous meningitis is defined as leptomeningeal infiltration by malignant cells. A case of carcinomatous meningitis, originally diagnosed as viral meningitis, is presented here to highlight the importance of maintaining a broad differential diagnosis in patients with evidence of meningeal irritation. Clinical and laboratory clues that suggest a diagnosis of carcinomatous meningitis in a patient with meningeal irritation include the presence and type of underlying malignancy (more common with breast cancer, lung cancer, and melanoma), absence of fever, presence of radicular pain, evidence of both cranial and spinal involvement, consistent cerebrospinal fluid (CSF) findings (increased opening pressure, elevated protein concentration, decreased glucose, increased white cell count), and supportive neuroimaging. Diagnosis is based on positive CSF cytology results, which may require multiple lumbar puncture procedures to obtain. For patients with a known primary malignancy who present to the emergency department with symptoms and/or signs of meningeal irritation, carcinomatous meningitis should be included in the differential diagnosis.

\section{RÉSUMÉ}

La méningite carcinomateuse se caractérise par une infiltration leptoméningée de cellules malignes. Nous présentons ici un cas de méningite carcinomateuse, diagnostiquée à l'origine comme une méningite virale, pour souligner l'importance de maintenir un large diagnostic différentiel chez les patients qui présentent des signes d'irritation méningée. Les signes cliniques et de laboratoire qui laissent présager un diagnostic de méningite carcinomateuse chez un patient atteint $d$ 'une irritation méningée comprennent la présence et le type de malignité sous-jacente (plus courants en présence d'un cancer du sein, d'un cancer du poumon et d'un mélanome), l'absence de fièvre, la présence de douleurs radiculaires, des preuves d'une atteinte crânienne et spinale, les mêmes constatations sur le liquide céphalorachidien (pression de déclenchement accrue, élévation de la concentration de protéines, baisse de la glycémie, hyperleucocytose), et la neuroimagerie de soutien. Le diagnostic est fondé sur les résultats cytologiques positifs des mêmes constatations sur le liquide céphalorachidien, lesquels peuvent nécessiter de multiples rachicenthèses. Chez les patients atteints d'une malignité principale confirmée qui se présentent aux urgences avec des symptômes et/ou des signes d'irritation méningée, la méningite carcinomateuse devrait être incluse dans le diagnostic différentiel.

Keywords: carcinomatous meningitis, cerebrospinal fluid cytology, meningitis

When a patient presents to the emergency department (ED) with symptoms consistent with meningitis, a wide variety of infectious agents are considered in the differential diagnosis. However, a number of noninfectious causes of meningitis should also be entertained in the appropriate clinical context. These include carcinomatous meningitis (in patients with underlying malignancy), sarcoidosis, Sjögren syndrome, Behçet disease, systemic lupus erythematosus and other collagen vascular diseases, vaccine reactions, and drug reactions. ${ }^{1}$ A case of carcinomatous meningitis, originally diagnosed as viral meningitis, is presented here. This case and the discussion that follows serve both to illustrate key clinical and laboratory

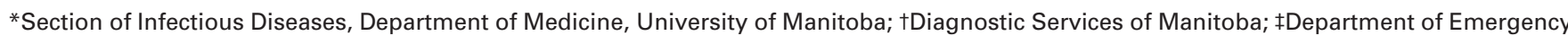
Medicine, University of Manitoba; §Department of Pathology, University of Manitoba, Winnipeg, MB
}

Correspondence to: Dr. Andrew Walkty, Diagnostic Services of Manitoba, Health Sciences Centre, MS673-820 Sherbrook Street, Winnipeg, MB R3A 1R9; awalkty@mts.net.

Submitted December 2, 2009; Revised March 22, 2010; Accepted April 10, 2010.

This article has been peer reviewed. 
features that may support a diagnosis of carcinomatous meningitis and to emphasize the setting in which this relatively rare clinical entity should be considered.

\section{CASE REPORT}

A 57-year-old Filipino woman, living in Canada for 10 years, presented to a community hospital ED in Winnipeg, Manitoba, with new onset of headache, low-grade fever, myalgias, and lethargy. The headache was described as fronto-occipital in location, and there was some associated nausea and emesis. The patient's symptoms began approximately 2 weeks prior to her presentation. She had previously been assessed by her family physician and received a prescription for erythromycin. This medication did not provide her with any significant symptom relief. There was no history of infectious contacts, nor was there any history of recent travel outside Canada. Eighteen months prior to presentation, the patient had been diagnosed with a $\mathrm{T} 3 \mathrm{~N} 1(\mathrm{~T} 3=$ primary tumour $>5 \mathrm{~cm}$ in size, $\mathrm{N} 1=$ metastasis to movable, ipsilateral axillary lymph nodes) high-grade, estrogen receptor-negative, progesterone receptor-negative, HER-2 (HER-2 = human epidermal growth factor receptor 2) receptor-negative, infiltrating ductal carcinoma of the right breast. Staging investigations performed at that time, including a bone scan and computed tomographic (CT) scanning of the chest and abdomen, did not demonstrate distant metastatic disease. The patient underwent a right modified mastectomy, followed by radiation and chemotherapy with curative intent. Her breast cancer treatment had been completed approximately 10 months prior to the development of her current symptoms. Her past medical history was also significant for hypertension. The only medications she was receiving at the time of presentation were atenolol and hydrochlorothiazide. The patient was employed as a sewing machine operator.

On physical examination, the patient was afebrile and hemodynamically stable. Nuchal rigidity was documented. The remainder of the physical examination was unremarkable. An noncontrast CT scan of the head failed to demonstrate any significant intracranial abnormality. A lumbar puncture was subsequently performed, and analysis of the cerebrospinal fluid (CSF) revealed an elevated cell count of 33 cells $/ \mathrm{mm}^{3}$ (97\% lymphocytes) (normal reference range up to 4 cells $/ \mathrm{mm}^{3}$ ), a mildly elevated protein of $0.73 \mathrm{~g} / \mathrm{L}$ (normal reference range 0.1 to $0.4 \mathrm{~g} / \mathrm{L}$ ), and a markedly depressed glucose of $0.9 \mathrm{mmol} / \mathrm{L}$ (corresponding serum glucose of $7.1 \mathrm{mmol} / \mathrm{L}, \mathrm{CSF}$ to serum glucose ratio of 0.12 ) (normal reference range 2.3 to $4.5 \mathrm{mmol} / \mathrm{L}$ ). Gram stain did not demonstrate bacteria, and the specimen was sterile on culture. The patient was diagnosed with aseptic meningitis, thought most likely to be of viral etiology. Given her clinical stability, admission was not felt to be necessary, and she was discharged home in the care of her family.

The patient returned to the same ED 9 days later with ongoing symptoms of headache, myalgias, and malaise. Her family also described a brief episode in which she lost consciousness and her eyes were reported to be "rolling." It was thought that this might have represented a seizure. Physical examination was significant for nuchal rigidity, a positive Kernig sign, and a positive Brudzinski sign. No focal neurologic abnormalities were appreciated. Her Glasgow Coma Scale score was 15. A repeat lumbar puncture was performed, and analysis of the CSF demonstrated an elevated cell count of 44 cells $/ \mathrm{mm}^{3}$ (normal reference range up to 4 cells $/ \mathrm{mm}^{3}$ ), a mildly elevated protein of $0.65 \mathrm{~g} / \mathrm{L}$ (normal reference range 0.1 to $0.4 \mathrm{~g} / \mathrm{L}$ ), and a depressed glucose of $1.2 \mathrm{mmol} / \mathrm{L}$ (corresponding serum glucose of $10.2 \mathrm{mmol} / \mathrm{L}, \mathrm{CSF}$ to serum glucose ratio of 0.12 ) (normal reference range 2.3 to $4.5 \mathrm{mmol} / \mathrm{L}$ ). In light of her clinical deterioration, the patient was admitted to hospital. In consultation with a specialist in infectious diseases, intravenous acyclovir was initiated for possible herpes simplex virus (HSV) encephalitis.

Magnetic resonance imaging (MRI) of the brain was performed 3 days postadmission. This revealed focal areas of $T_{2}$ hyperintensity anteriorly in the left temporal lobe and areas of enhancement in the cingulate gyrus to the left of the midline. A postgadolinium $\mathrm{T}_{1}$-weighted MRI is presented in Figure 1. The findings were potentially consistent with HSV encephalitis, but leptomeningeal metastatic disease was also considered to be a possibility. Bacterial culture, culture for enterovirus, cryptococcal antigen testing, mycobacterial and fungal stains, and HSV polymerase chain reaction assay were all negative for pathogens from the second lumbar puncture. Given the patient's history of previous breast cancer and the possibility of metastatic disease on MRI, a third lumbar puncture was performed for cytology. This yielded malignant cells, consistent with metastatic carcinoma (Figure 2). Based on the clinical presentation, compatible neuroimaging, 


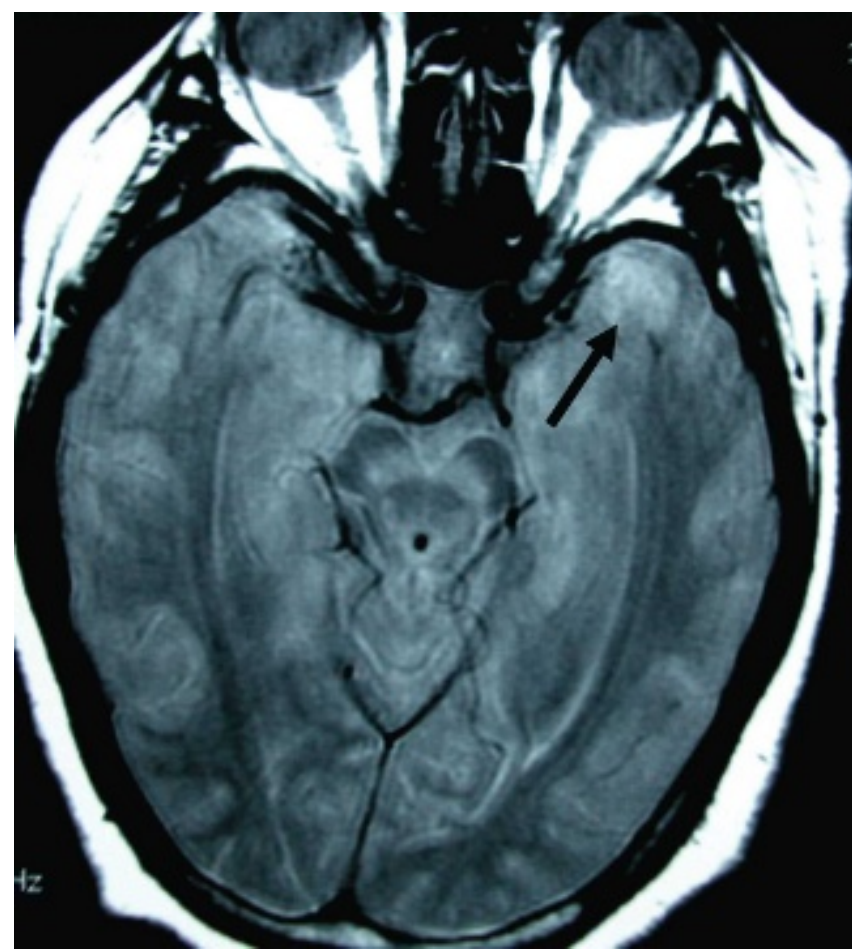

Figure 1. Postgadolinium $\mathrm{T}_{1}$-weighted magnetic resonance image. An abnormal area of blood-brain barrier breakdown is observed in the left anterior temporal lobe (arrow).

and the CSF results, the patient was diagnosed with carcinomatous meningitis. Over the course of her admission, her clinical condition deteriorated. She became increasingly somnolent and ultimately lapsed into a comatose state. In light of her poor overall prognosis, the family made an informed decision to pursue a palliative approach. The patient expired on the tenth day postadmission.

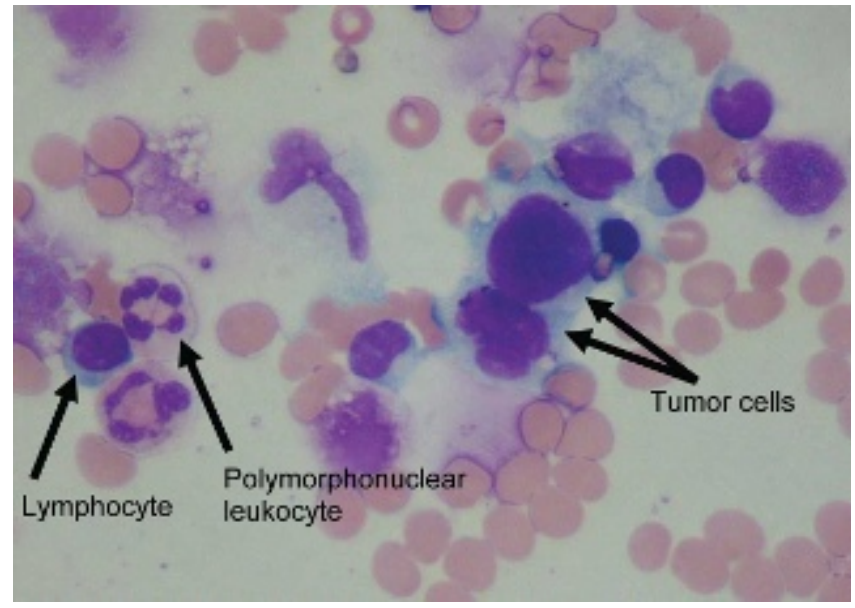

Figure 2. Tumour cells in the cerebrospinal fluid.

\section{DISCUSSION}

Carcinomatous meningitis is defined as an infiltration of the leptomeninges (the arachnoid membrane and the pia mater) by malignant cells. ${ }^{2-4}$ This condition, synonymous with the terms leptomeningeal carcinomatosis and meningeal carcinomatosis, is an uncommon manifestation of malignancy. ${ }^{2,3}$ It is estimated to occur in approximately 3 to $8 \%$ of patients with solid tumours. ${ }^{2,3,5}$ The solid tumours most often associated with leptomeningeal spread are carcinoma of the breast (as with our patient), carcinoma of the lung, and malignant melanoma. ${ }^{2-6}$ Carcinomatous meningitis usually occurs in patients with a known primary malignancy. In up to 10 to $20 \%$ of cases, however, symptoms secondary to carcinomatous meningitis may precede diagnosis of the primary tumour. ${ }^{7,8}$

Spread of malignant cells to the leptomeninges occurs most commonly by either hematogenous dissemination or direct extension from pre-existing systemic or central nervous system tumours. ${ }^{5}$ Patients often present with a combination of cranial nerve, cerebral, and spinal signs and symptoms, reflecting the multifocal nature of this disease. ${ }^{3,6,8}$ Common symptoms include headache, a change in mental status, back or radicular pain, nausea, vomiting, limb weakness, sensory complaints, diplopia, dysphagia, dysarthria, and incoordination. ${ }^{2-7}$ Signs may include alteration in mental status, cranial nerve palsies, asymmetry of deep tendon reflexes, lower motor neuron weakness, and sensory deficits..$^{2-7}$ Seizures may occur owing to infiltration of the brain parenchyma. ${ }^{2}$ Of note, nuchal rigidity is present in only 7 to $17 \%$ of cases and fever is typically absent. ${ }^{2-7}$

The diagnosis of carcinomatous meningitis is based primarily on examination of the CSF., ${ }^{3,9}$, The CSF is almost always abnormal., ${ }^{4,6} \mathrm{CSF}$ analysis demonstrates an elevation of the opening pressure in at least $50 \%$ of cases, a decrease in the glucose concentration in 30 to $50 \%$ of cases (may be less than $70 \%$ of the corresponding serum glucose), an elevation in the protein concentration in 70 to $90 \%$ of cases, and an elevation in the white cell count (lymphocyte predominance, usually less than 100 cells $\left./ \mathrm{mm}^{3}\right) .^{2-7}$ The CSF abnormalities found in patients with carcinomatous meningitis are contrasted with those found in infectious meningitis in Table $1 .^{10-12}$ Recall that analysis of our patient's CSF revealed an elevated protein concentration, a low glucose, and an elevated white cell count. It should be emphasized that the markedly reduced 
Table 1. Cerebrospinal fluid findings in carcinomatous meningitis in comparison with infectious causes of meningitis ${ }^{2-7,10-12}$

\begin{tabular}{|c|c|c|c|}
\hline \multirow[b]{2}{*}{ Etiology } & \multicolumn{3}{|c|}{ CSF parameter } \\
\hline & $\begin{array}{l}\text { Cell count (normal }=\text { up to } 4 \\
\text { cells } / \mathrm{mm}^{3} \text {, all lymphocytes) }\end{array}$ & Protein (normal $=0.1-0.4 \mathrm{~g} / \mathrm{L}$ ) & $\begin{array}{l}\text { Glucose }(\text { normal }= \\
2.3-4.5 \mathrm{mmol} / \mathrm{L})\end{array}$ \\
\hline Carcinomatous meningitis & $\begin{array}{l}\text { Usually }<100 \text { cells } / \mathrm{mm}^{3} \text {, } \\
\text { lymphocyte predominance }\end{array}$ & Increased in $70-90 \%$ of cases & $\begin{array}{l}\text { Decreased in } 30-50 \% \text { of cases } \\
\text { (may be }<70 \% \text { of the } \\
\text { corresponding serum value) }\end{array}$ \\
\hline Bacterial meningitis & $\begin{array}{l}<100 \text { to }>10,000 \text { cells } / \mathrm{mm}^{3} \text { (usual } \\
\text { is }>1,000 \text { cells } / \mathrm{mm}^{3} \text { ), neutrophil } \\
\text { predominance }\end{array}$ & Increased & $\begin{array}{l}\text { Decreased }(<2.2 \mathrm{mmol} / \mathrm{L} \text { or } \\
\mathrm{CSF} / \text { serum glucose ratio } \\
\text { of }<0.4)\end{array}$ \\
\hline Viral meningitis & $\begin{array}{l}10 \text { to } 1,000 \text { cells } / \mathrm{mm}^{3} \text {, lymphocyte } \\
\text { predominance }\end{array}$ & Normal or slightly increased & Normal \\
\hline Tuberculous meningitis & $\begin{array}{l}10 \text { to } 1,000 \text { cells } / \mathrm{mm}^{3} \text {, lymphocyte } \\
\text { predominance }\end{array}$ & Increased & $\begin{array}{l}\text { Decreased (approximately } \\
1.6-2.5 \mathrm{mmol} / \mathrm{L})\end{array}$ \\
\hline Fungal meningitis & $\begin{array}{l}10 \text { to } 1,000 \text { cells } / \mathrm{mm}^{3} \text {, lymphocyte } \\
\text { predominance }\end{array}$ & Increased & Decreased \\
\hline
\end{tabular}

glucose concentration seen in our patient's CSF $(<80 \%$ of the corresponding serum value) was not in keeping with a typical case of viral meningitis (see Table 1). Cytology is diagnostic on the first lumbar puncture in 50 to $70 \%$ of cases. ${ }^{2-6,9}$ The diagnostic yield increases to $>90 \%$ with three lumbar punctures. ${ }^{3,4,9}$ Neuroimaging may support the diagnosis of carcinomatous meningitis. Findings on MRI may include contrast enhancement of the meninges, sulci, basilar cisterns, and cauda equina and hydrocephalus. ${ }^{5}$ Imaging may also demonstrate the presence of concomitant parenchymal metastases. ${ }^{8}$ Treatment options for carcinomatous meningitis include radiation and intrathecal chemotherapy. ${ }^{2-5}$ However, the overall prognosis remains poor. Survival duration without treatment is approximately 6 weeks, and the median survival duration with treatment is approximately 3 to 6 months. ${ }^{3,5,6,8}$

\section{SUMMARY}

In a patient with a known primary malignancy presenting with symptoms and/or signs of meningeal irritation, it is important to consider carcinomatous meningitis in the differential diagnosis. Clinical and laboratory clues that may lend support to a diagnosis of carcinomatous meningitis include the type of malignancy (more common with breast cancer, lung cancer, and melanoma), absence of fever, presence of radicular pain, evidence of both cranial and spinal involvement, consistent CSF findings (increased opening pressure, elevated protein concentration, decreased glucose, increased white cell count), and typical MRI findings. ${ }^{8}$
Diagnosis depends on positive CSF cytology results, which may require multiple lumbar puncture procedures to obtain.

Acknowledgement: The authors wish to acknowledge Dr. Jack Lezack for his review of the manuscript.

Competing interests: None declared.

\section{REFERENCES}

1. Lee BE, Davies HD. Aseptic meningitis. Curr Opin Infect Dis 2007;20:272-7, doi:10.1097/QCO.0b013e3280ad4672.

2. Pavlidis $\mathrm{N}$. The diagnostic and therapeutic management of leptomeningeal carcinomatosis. Ann Oncol 2004;15 Suppl 4:iv285-91.

3. Zachariah B, Zachariah SB, Varghese R, et al. Carcinomatous meningitis: clinical manifestations and management. Int 7 Clin Pharmacol Ther 1995;33:7-12.

4. Taillibert S, Laigle-Donadey F, Chodkiewicz C, et al. Leptomeningeal metastases from solid malignancy: a review. 7 Neurooncol 2005;75:85-99, doi:10.1007/s11060-0048101-x.

5. Grossman SA, Krabak MJ. Leptomeningeal carcinomatosis. Cancer Treat Rev 1999;25:103-19, doi:10.1053/ctrv.1999. $\underline{0119}$.

6. Wasserstrom WR, Glass JP, Posner JB. Diagnosis and treatment of leptomeningeal metastases from solid tumors: experience with 90 patients. Cancer 1982;49:759-72, doi:10.1002/1097-0142 (19820215)49:4<759::AID-CNCR2820490427>3.0.CO;2-7.

7. Balm M, Hammack J. Leptomeningeal carcinomatosis: presenting features and prognostic factors. Arch Neurol 1996;53:626-32.

8. Hildebrand J, Aoun M. Chronic meningitis: still a diagnostic challenge. $f$ Neurol 2003;250:653-60, doi:10.1007/s00415003-1101-5. 
9. Glantz MJ, Cole BF, Glantz LK, et al. Cerebrospinal fluid cytology in patients with cancer: minimizing false-negative results. Cancer 1998;82:733-9, doi:10.1002/(SICI)10970142(19980215)82:4<733::AID-CNCR17>3.0.CO;2-Z.

10. Roos KL, Tyler KL. Bacterial meningitis and other suppurative infections. In: Braunwald E, Fauci AS, Kasper DL, et al, editors. Harrison's principles of internal medicine. 15th ed. New York: McGraw-Hill; 2001. p. 2462-7.
11. Begg N, Cartwright KAV, Cohen J, et al. Consensus statement on diagnosis, investigation, treatment and prevention of acute bacterial meningitis in immunocompetent adults. 7 Infect 1999;39:1-15, doi:10.1016/S01634453(99)90095-6.

12. Greenlee JE. Approach to diagnosis of meningitis: cerebrospinal fluid evaluation. Infect Dis Clin North Am 1990;4: 583-98. 